Jurnal Semarak, Vol. 1,No.3,Oktober 2018 , Hal (122-141)

@Prodi Manajemen Fakultas Ekonomi Universitas Pamulang

\title{
PENGARUH KOMITMEN ORGANISASI DAN KOMPENSASI TERHADAP KEPUASAN KERJA SERTA DAMPAKNYA TERHADAP KINERJA KARYAWAN
}

(Pada Sub Direktorat Penindakan Bea dan Cukai)

\author{
Angga Pratama
}

Dosen Fakultas Ekonomi Universitas Pamulang

Email : dosen02155@unpam.ac.id atau anggapratama.unpam@gmail.com

\begin{abstract}
ABSTRAK
Penelitian ini bertujuan untuk mengetahui pengaruh komitmen organisasi terhadap Kepuasan Kerja secara Parsial pada Sub Direktorat Penindakan Bea Dan Cuka Mengetahui Pengaruh Kompensasi terhadap Kepuasan Kerja secara Parsial pada Sub DirektoratPenindakanBeaDanCukai.Mengetahui Pengaruh Komitmen Organisasi dan Ko mpensasi pada Kepuasan Kerja Simultan pada Sub Direktorat Penindakan Bea Dan Cukai Mengetahui Pengaruh Komitmen Organisasi terhadap Kinerja Karyawan secara Parsial pada Sub Direktorat Penindakan Bea Dan Cukai Mengetahui Pengaruh Kompensasi terhadap Kinerja Karyawan secara Parsial pada Sub Direktorat Penindakan Bea Dan Cukai Mengetahui Pengaruh Kepuasan Kerja terhadap Kinerja Karyawan secara Parsial pada Sub Direktorat Penindakan Bea Dan Cukai. Penelitian ini merupakan studi analisis deskriptifkualitatif dengan mengunakan alat ukur analisis regresi linier sederhana dan berganda. Jenis data yang digunakan dalam penelitian ini adalah data primer. Jenis data primer dalam penelitian ini yaitu berupa hasil dari kuesioner yang diberikan pada 100 orang responden. Data yang diperoleh kemudian diolah menggunakan bantuan Program SPSS For Windows Ver. 24.Dari pengujian regresi linier sederhana maupun berganda,diperolehhasilbahwa secaraparsial komitmen organisasi memiliki pengaruh pos itif dan signifikan terhadap kepuasan kerja dengan diperoleh nilai 5,025 dan signifikansi sebesar0,000.Kompensasi memiliki pengaruh positifdan signifikan terhadap kepuasan ke rja secaraparsialdengan diperoleh nilai t sebesar 2,720dannilai signifikansi sebesar 0,009. Komitmen organisasi dan kompensasi memiliki pengaruh positif dan signifikan dengan diperoleh nilai $\mathrm{f}$ sebesar 13,427 dan nilai signifikansi sebesar 0,000 . Komitmen organisasi berpengaruh positif dan signifikan terhadap kinerja karyawan dengan diperoleh nilai t sebesar 4,638 dan nilai signifikansi sebesar 0,000. Kompensasi berpengaruh positif dan signifikan terhadap kinerja karyawan dengan diperoleh nilai t sebesar 2,811 dan nilai signifikansi sebesar 0,006. kepuasan kerja berpengaruh positif dan signifikan terhadap kinerja karyawan dengan diperoleh nilai t sebesar 18,941 dan nilai signifikansi sebesar 0,000.
\end{abstract}

KataKunci:Komitmen Organisasi,Kompensasi,Kepuasan dan Kinerja Karyawan

\section{PENDAHULUAN}

\section{A. Latar Belakang Masalah}

Meningkatnya persaingan

bisnis di dunia bisnis saat ini mengharuskan perusahaan untuk

mendapatkan manfaat dari

kemampuan yang ada hingga maksimal untuk Unggul dalam

kompetisi. Apalagi, perkembangan 
JURNAL

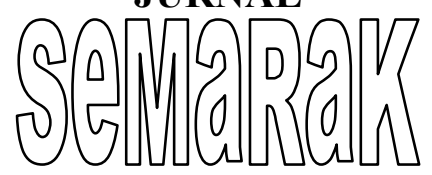

P-ISSN 2615-6849 E-ISSN 2622-3686

Semarak,Vol. 1, No.3,Oktober 2018, Hal (1-20)

@Prodi Manajemen Fakultas Ekonomi Universitas Pamulang bisnis di Indonesia sedang melewati masa yang sulit. Krisis moneter mempengaruhi semua Aspek kehidupan manusia belum berakhir. lebih pintar dalam menemukan peluang pasar. Perusahaan yang beroperasi tidak efektif dan efisien tidak dapat mempertahankan kontinuitas hidup mereka. Perusahaan di sini sebagai organisasi perdagangan adalah Penyedia produk dan layanan sehingga perusahaan memiliki tujuan utama untuk mendapatkan laba maksimal untuk mempertahankan hidupnya.

Suatu lembaga, baik lembaga negara maupun organisasi yang disebut lembaga, harus mengambil tindakan untuk mencapai tujuannya yang dikelola oleh sekelompok orang yang memainkan peran aktif dalam mencapai tujuan organisasi.Organisas i perusahaan ini benar-benar memiliki hubungan erat antara kerja individu dan aktivitas perusahaan. Dengan kata lain, jika kinerja karyawan baik, kinerja perusahaan juga dimungkinkan. Kinerja karyawan juga baik jika ia memiliki pengalaman yang tinggi, siap bekerja karena ia dibayar oleh kontrak dan memiliki harapan masa depan yang lebih baik.

Sumber daya manusia organisasi merupakan faktor yang sangat penting dalam efisiensi dan efektifitas organisasi. Ada kebutuhan untuk sumber daya manusia yang ada untuk berkontribusi pada pelaksanaan organisasi. Ada sejumlah faktor yang mempengaruhi tujuan - tujuan ini meliputi factor organisasi intern sebagai komitmen organisasi, kompensasi, kepuasan karyawan, dimana komponennya memiliki peran dalam menentukan kinerja karyawan Triyono (2008: 35). kinerja performa lebih tinggi menyiratkan peningkatan dalam keefisiensian, keefektifan, atau kadar yang lebih tinggi daripada menyelesaikan serangkaian tugas yang ditugaskan dan di tujukan ke seseorang karyawan di dalamnya sebuah organisasi, Murty and Hudiwinarsih (2012: 215). Komitmen organisasi juga mempengaruhi kinerja karyawan. Secara teoretis sebuah komitmen organisasi mempengaruhi beberapa perilaku penting sehingga organisasi berfungsi secara efektif. Gibson, Ivancevich \& Donnelly (2010: 102) menyatakan bahwa tanpa komitmen akan mengurangi efektivitas organisasi. Karyawan dengan tingkat keterlibatan tinggi cenderung tinggal di organisasi atau perusahaan. Keterlibatan yang tinggi mengurangi kebutuhan akan pengawasan, keterlibatan yang tinggi dalam mengkoordinasikan tujuan pribadi dengan tujuan organisasi. Pengaruh keterlibatan tinggi menunjukkan kepercayaan diri yang kuat dan dukungan untuk tujuan organisasi. Karyawan dengan tingkat keterlibatan tinggi berusaha mencapai tujuan organisasi dan karyawan dengan tingkat keterlibatan tinggi memiliki pandangan positif dan sikap terhadap organisasi dan berusaha melakukan yang terbaik untuk kepentingan organisasi, Porter (2002: 156). Dengan kata lain, karyawan dengan komitmen tingkat tinggi akan peduli tentang meningkatkan nasib organisasi dan organisasi. Darlis (2002: 124). Robbins (2007: 256), 
JURNAL

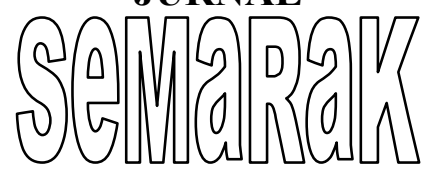

\section{P-ISSN 2615-6849 E-ISSN 2622-3686}

Semarak,Vol. 1, No.3,Oktober 2018, Hal (1-20)

@ Prodi Manajemen Fakultas Ekonomi Universitas Pamulang menyatakan bahwa karyawan dengan komitmen tinggi akan membawa kesuksesan bagi organisasi.

1. Selain komitmen organisasi, mencapai tujuan organisasi ke arah yang lebih baik membutuhkan motivasi, baik secara internal maupun

2. eksternal. Motivasi internal adalah motivasi yang muncul dari pikiran, hati dan rasa diri. Motivasi eksternal adalah motivasi yang muncul melalui dorongan dari luar orang, misalnya dari orang lain dan organisasi tempat mereka bekerja.

3. Menurut Armstrong dalam Badjuri (2009: 118) motivasi adalah sesuatu atau kekuatan yang mendorong seseorang untuk mengambil tindakan atau perilaku tertentu dengan cara tertentu. Sedangkan Reksohadipraja dalam Badjuri (2009 : 118 - 119) mendefinisikan motivasi sebagai kondisi motivasi pribadi seseorang untuk melakukan aktivitas tertentu untuk mencapai suatu tujuan. Karena karyawan memiliki motivasi untuk menyelesaikan pekerjaan mereka dan sebagai sesuatu yang menyenangkan, karena karyawan biasanya akan mendapatkan kepuasan dari kinerja tinggi karyawan mereka. Karyawan dapat diberikan tanggung jawab yang lebih luas untuk membuat keputusan dan melakukan tugas karyawan, karena karyawan sudah memiliki dorongan untuk bekerja dengan baik dan mampu mencapai tujuan bisnis dengan cara yang baik. Motivasi sangat penting bagi perusahaan karen a motivasi adalah bagian dari kegiatan perusahaan dalam proses mengasuh, mengembangkan dan memimpin orang dalam pekerjaan. Ketika melakukan pekerjaan, seorang karyawan harus termotivasi sehingga dapat mendorong, sehingga karyawan dapat bekerja keras dan merasa puas dengan pekerjaannya.

4. Kepuasan kerja adalah individu di mana setiap individu memiliki tingkat kepuasan yang berbeda. Kepuasan yang dirasakan oleh setiap individu atau karyawan merupakan kesimpulan berdasarkan apa yang Anda dapatkan langsung dari pekerjaan dengan apa yang Anda inginkan atau hasilkan oleh karyawan. Kepuasan kerja adalah masalah yang cukup menarik dan penting yang bermanfaat bagi individu, industri dan masyarakat, M.As'ad, di Misran (2004: 1). Untuk karyawan, pemahaman pribadi tentang penyebab dan sumber kepuasan kerja memunculkan usaha bisnis untuk mereka dan untuk mengetahui lebih banyak. Perusahaan, kepuasan kerja sudah selesai untuk meningkatkan kinerja melalui dan karyawan serta keterampilan karyawan. Selanjutnya, untuk komunitas tertentu mereka akan menikmati produksi maksimum dari perusahaan.

5. Kepuasan kerja adalah salah satu faktor yang terlibat dalam pekerjaan karyawan. Kepuasan kerja adalah keadaan emosional di mana hal itu terjadi atau tidak terjadi antara titik pertemuan rata-rata remunerasi karyawan perusahaan atau organisasi 
JURNAL

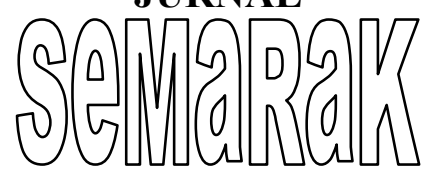

\section{P-ISSN 2615-6849 E-ISSN 2622-3686}

Semarak,Vol. 1, No.3,Oktober 2018, Hal (1-20)

@Prodi Manajemen Fakultas Ekonomi Universitas Pamulang dengan tingkat remunerasi yang memang diinginkan oleh karyawan yang berdiskusi dan membahas. Martoyo (2007: 156). Menurut Mudiartha (2001: 257) penyebab beragam ketidakpuasan, seperti e-mail yang rendah atau menyenangkan tidak mencukupi, kondisi kerja yang tidak memadai, hubungan yang tidak harmonis dengan pengusaha dan rekan kerja serta proyek yang tidak tepat.

6. Kepuasan kerja tidak diperoleh dari status sosial yang tinggi, tetapi kepuasan untuk bekerja bagi mereka adalah upaya untuk mencapai produksi itu sendiri.

Manajemen harus mendorong sumber daya manusia untuk tetap produktif dalam memenuhi tugasnya masing masing,

yaitu dengan meningkatkan kepuasan kerja yang dapat dipertahankan oleh karyawan. Kecuali bahwa karyawan juga dapat menjadi mitra yang baik untuk mendukung solusi bagi organisasi, memotivasi pekerjaan sementara karyawan diterima. penghargaan untuk pekerjaan yang mereka lakukan.

7. Kepuasan kerja sangat penting

bagi semua karyawan,karena dapat

meningkatkan produktivitas

dan

mengurangi perputaran karyawan. Menurut

Syptak

(1999:

110),

Kepuasan kerja merupakan elemen penting dalam situasi kerja dan dikaitkan dengan peningkatan kinerja dan peningkatan komitmen terhadap organisasi, Gathungu (2013: 18). Robbins (2003: 10) menyatakan Kepuasan kerja itu mengacu pada sikap individu pada umumnya terhadap pekerjaan mereka.

Seseorang dengan tingkat kepuasan kerja yang tinggi memiliki sikap positif terhadap pekerjaannya, sementara seseorang yang tidak puas dengan pekerjaannya memiliki sikap negatif terhadap pekerjaannya. Pernyataan ini menunjukkan bahwa setiap individu memiliki tingkat kepuasan karyawan yang berbeda antara satu karyawan dan karyawan lain. Hasil studi Ncube dan Samuel (2014: 117) menunjukkan bahwa variabel motivasi intrinsik dan ekstrinsik memiliki dampak yang signifikan terhadap kepuasan kerja. Manajemen dapat mengembangkan praktik kepuasan kerja dan mengidentifikasi variabel motivasi untuk memaksimalkan produktivitas karyawan dan meningkatkan kualitas layanan.

Peran sumber daya manusia sangat penting untuk mencapai tujuan perusahaan. Di mana sumber daya manusia adalah modal perusahaan, di samping teknologi dan ketersediaan dana. Dalam banyak persaingan bisnis yang sulit dan kemajuan teknologi yang cepat, perusahaan akan mengambil cara yang berbeda untuk bertahan hidup. Karena itu, perusahaan akan lebih memperhatikan pengembangan sumber daya manusia.

Dalam suatu organisasi, faktor sumber daya manusia memainkan peran penting dibandingkan dengan faktor-faktor lain. Jika organisasi gagal mencapai tujuannya, faktor manusia dapat menjadi penyebabnya. Karena itu, karyawan perlu dorongan atau 


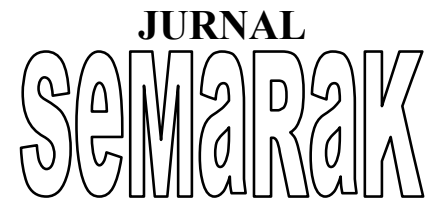

Semarak,Vol. 1, No.3,Oktober 2018, Hal (1-20)

@Prodi Manajemen Fakultas Ekonomi Universitas Pamulang

motivasi untuk bekerja lebih baik untuk mencapai kinerja yang baik. Untuk melihat pentingnya orang dalam mencapai tujuan organisasi, harus ada manajemen yang mengelola manajemen sumber daya manusia.

$$
\text { Kinerja adalah hal yang }
$$

penting dalam suatu perusahaan untuk

mencapai tujuannya. Kinerja karyawan merupakan salah satu faktor yang paling dominan dalam meningkatkan kinerja perusahaan. Menurut Mathis (2006: 48) ada tiga faktor utama yang mempengaruhi kinerja, (1) keterampilan adalah: bakat, minat, faktor kepribadian, (2) upaya adalah motivasi, etika kerja, absensi, desain tugas, (3) organisasi pendukung meliputi: pelatihan dan pengembangan, peralatan dan teknologi, standar kinerja dan manajemen dan rekan kerja.

\section{Untuk}

meningkatkan produktivitas kerja karyawan, faktor yang paling berpengaruh adalah kompensasi untuk karyawan, karena jumlah kompensasi yang diterima oleh karyawan sangat penting dalam memotivasi karyawan untuk dapat bekerja lebih aktif, sehingga setiap perusahaan diharapkan untuk memperhatikan aspek kompensasi karyawan yang sesuai. dengan kemampuan karyawan untuk menghasilkan produk berkualitas lebih baik, Heidjrahman dan Suad Husnan (2002: 15).

\section{Identifikasi Masalah}

Berdasarkan latar belakang masalah yang telah dikemukakan di atas, maka peneliti ingin mengidentifikasi masalah pada hal-hal berikut ini:

1. Kompensasi materi dan non materi yang diberikan Sub Direktorat Penindakan Bea dan
Cukai kepada pegawai belum memenuhi harapan pegawai

2. Produktivitas kerja Sub Direktorat Penindakan Bea dan Cukai yang masih rendah

3. Kepuasan kerja pegawai Sub Direktorat Penindakan Bea dan Cukai yang masih rendah

4. Kurang berkomitmennya pegawai Sub Direktorat Penindakan Bea dan Cukai dalam bekerja

5. Perlakuan Sub Direktorat Penindakan Bea dan Cukai kepada para pegawainya belum optimal

6. Kinerja karyawan Sub Direktorat Penindakan Bea dan Cukai belum maksimal

\section{B. Batasan Masalah}

Berdasarkan latar belakang yang dikemukakan di atas yang cukup luas agar tujuan penelitian dapat tercapai, maka penulis membatasi masalah penelitian, yaitu :

1. Yang dimaksud komitmen organisasi dalam penelitian ini adalah suatu ikatan psikologis karyawan pada organisasidimana karyawan yakin dan menerima tujuan organisasi serta berkeinginan untuk tinggal bersama organisasi.

2. Yang dimaksud kompensasi pada penelitian ini adalah semua bentuk balas jasa uang dan semuabarang atau komoditas yang digunakan sebagai balas jasa uang kepada karyawan baik secara langsung ataupun tidak langsung.

3. Yang dimaksud kepuasan kerja alam penelitian ini adalah perilaku individual terhadap pekerjaannya yang merupakan keadaan emosionalyang positif atas hasil dari evaluasi pengalaman kerja seseorang.

4. Yang dimaksud kinerja karyawan dalam penelitian ini 
JURNAL

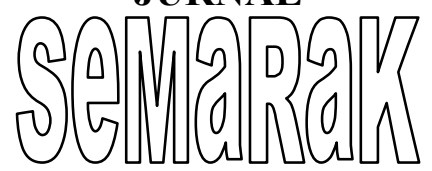

Semarak,Vol. 1, No.3,Oktober 2018, Hal (1-20)

@Prodi Manajemen Fakultas Ekonomi Universitas Pamulang

adalahperwujudan kerja yang dilakukan oleh karyawan atau perilaku nyata yang ditampilkan setiap orang sebagai prestasi kerja yang dihasilkan oleh karyawan sesuai dengan perannya dalam perusahaan.

\section{Perumusan Masalah}

Berdasarkan latar belakang yang telah di uraikan di atas, permasalahan yang akan dibahas dalam penelitian ini adalah:

1. Apakah komitmen organisasimempunyai pengaruhsignifikan kepuasan kerja terhadap karyawanSub Direktorat Penindakan Bea dan Cukai?

2. Apakah kompensasi mempunyai pengaruh yang signifikan terhadap kepuasan kerja pada karyawanSub Direktorat Penindakan Bea dan Cukai?

3. Apakah komitmen organisasi dan kompensasi mempunyai pengaruh yang signifikan terhadap kepuasan kerjapada karyawan Sub Direktorat Penindakan Bea dan Cukai?

4. Apakah komitmen organisasi mempunyai pengaruhsignifikan terhadap kinerja karyawan pada karyawanSub Direktorat Penindakan Bea dan Cukai?

5. Apakah kompensasi mempunyai pengaruh yang signifikan terhadap kinerja karyawan pada karyawanSub Direktorat Penindakan Bea dan Cukai?

6. Apakah kepuasan kerja mempunyai pengaruh yang signifikan terhadap kinerja karyawan padaSub Direktorat Penindakan Bea dan Cukai?

\section{Tujuan Penelitian}

Setelah melihat latar belakang dan permasalahan yang telah dipaparkan, peneliti tertarik meneliti pengaruh komitmen organisasi dan kompensasi terhadap kepuasan kerja serta dampaknya terhadap kinerja karyawan. Tujuan dari penelitian ini adalah:

1. Untuk mengetahui dan menganalisis pengaruh komitmen organisasi terhadap kepuasan kerja secara parsial pada karyawanSub Direktorat Penindakan Bea dan Cukai?

2. Untuk mengetahui dan menganalisis pengaruh kompensasi terhadap kepuasan kerja secara parsial pada karyawanSub Direktorat Penindakan Bea dan Cukai?

3. Untuk mengetahui dan menganalisis pengaruh komitmen organisasi dan kompensasi terhadap kepuasan kerja secara simultan pada karyawan Sub Direktorat Penindakan Bea dan Cukai?

4. Untuk mengetahui dan menganalisis pengaruh komitmen organisasi terhadap kinerja karyawan secara parsial pada karyawanSub Direktorat Penindakan Bea dan Cukai?

5. Untuk mengetahui dan menganalisis pengaruh kompensasi terhadap kinerja karyawan pada secara parsial karyawanSub Direktorat Penindakan Bea dan Cukai?

6. Untuk mengetahui dan menganalisis pengaruh kepuasan kerjaterhadap kinerja karyawan secara parsial padaSub Direktorat Penindakan Bea dan Cukai?

BAB IV

PEMBAHASAN

DAN

HASIL

\section{PENELITIAN}

\section{A. Gambaran Umum Objek Penelitian}

1. Sejarah Objek Penelitian 
JURNAL

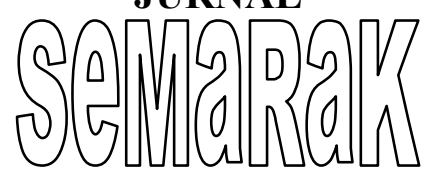

Semarak,Vol. 1, No.3,Oktober 2018, Hal (1-20)

@Prodi Manajemen Fakultas Ekonomi Universitas Pamulang

CUSTOMS (Instansi
Kepabeanan) adalah suatu
organisasi yang keberadaannya sangat essensial bagi suatu negara, demikian pula dengan Direktorat Jenderal Bea dan Cukai (Instansi Kepabeanan Indonesia) adalah suatu instansi yang memiliki peran yang cukup penting pada suatu negara. Bea dan Cukai (selanjutnya kita sebut Bea Cukai) merupakan institusi global yang hampir semua negara di dunia memilikinya.Bea Cukai merupakan perangkat negara "konvensional" seperti halnya kepolisian, kejaksaan, pengadilan, ataupun angkatan bersenjata, yang eksistensinya telah ada sepanjang masa sejarah negara itu sendiri.Fungsi Bea Cukai di Indonesia diyakini sudah ada sejak zaman kerajaan dahulu, namun belum ditemukan bukti-bukti tertulis yang kuat.Kelembagaannya pada waktu itu masih bersifat "lokal" sesuai wilayah kerajaannya.Sejak VOC masuk, barulah Bea Cukai mulai terlembagakan secara "nasional".Pada masa Hindia Belanda tersebut, masuk pula istilah douane untuk menyebut petugas Bea Cukai (istilah ini acapkali masih melekat sampai saat ini). Nama resmi Bea Cukai pada masa Hindia Belanda tersebut adalah De Dienst der Invoer enUitvoerrechten en Accijnzen (I. U \& A) atau dalam terjemah

bebasnya berarti "Dinas Bea Impor dan Bea Ekspor serta Cukai”. Tugasnya adalah memungut invoer-rechten (bea impor/masuk), uitvoer-rechten (bea ekspor/keluar), dan accijnzen (excise/ cukai). Tugas memungut bea ("bea" berasal dari bahasa Sansekerta), baik impor maupun ekspor, serta cukai (berasal dari bahasa India) inilah yang kemudian memunculkan istilah Bea dan Cukai di Indonesia.

Peraturan yang melandasi saat itu di antaranya Gouvernment Besluit Nomor 33 tanggal 22 Desember 1928 yang kemudian diubah dengan keputusan pemerintah tertanggal 1 Juni 1934. Pada masa pendudukan Jepang, berdasarkan Undang-undang Nomor 13 tentang Pembukaan Kantor-kantor Pemerintahan di Jawa dan Sumatera tanggal 29 April 1942, tugas pengurusan bea impor dan bea ekspor ditiadakan, Bea Cukai sementara hanya mengurusi cukai saja. Lembaga Bea Cukai setelah Indonesia merdeka, dibentuk pada tanggal 01 Oktober 1946 dengan nama Pejabatan Bea dan Cukai. Saat itu Menteri Muda Keuangan, Sjafrudin Prawiranegara, menunjuk R.A Kartadjoemena sebagai Kepala Pejabatan Bea dan Cukai yang pertama.Jika ditanya kapan hari lahir Bea Cukai Indonesia, maka 1 Oktober 1946 dapat dipandang sebagai tanggal yang tepat.

Berdasarkan Peraturan Pemerintah Nomor 51 tahun 1948, istilah Pejabatan Bea Cukai berubah menjadi nama menjadi Jawatan Bea dan Cukai, yang bertahan sampai tahun 1965. Setelah tahun 1965 hingga Page 128 
JURNAL

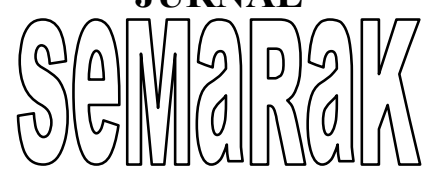

Semarak,Vol. 1, No.3,Oktober 2018, Hal (1-20)

@ Prodi Manajemen Fakultas Ekonomi Universitas Pamulang

sekarang, namanya menjadi Direktorat Jenderal Bea dan Cukai (DJBC).

\section{Struktur Organisasi}

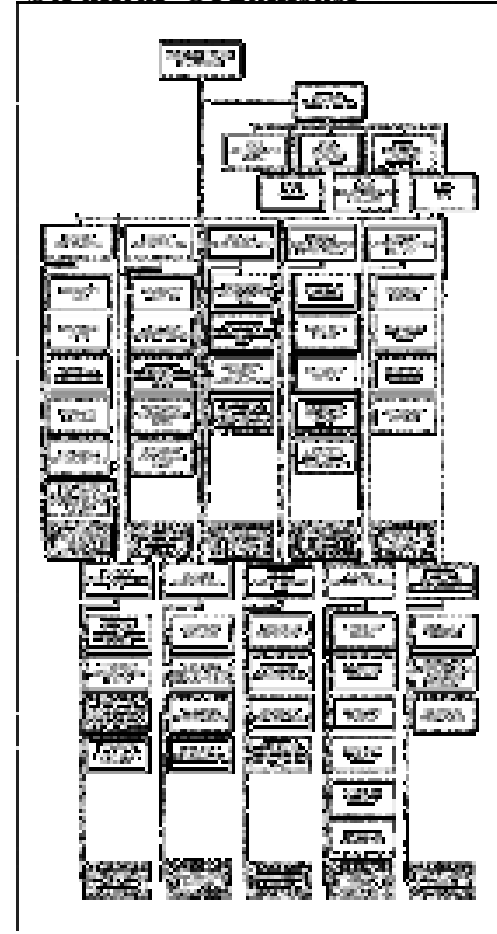

Gambar 4.1

\section{Struktur Organisasi Direktorat Jenderal}

\section{Bea dan Cukai}

\section{Tugas}

Direktorat Jenderal Bea dan

Cukai berada di bawah dan bertanggung jawab kepada Menteri Keuangan dan dipimpin oleh Direktur Jenderal Bea dan Cukai.Direktorat Jenderal Bea dan Cukai mempunyai tugas menyelenggarakan perumusan dan pelaksanaan kebijakan di bidang pengawasan, penegakan hukum, pelayanan dan optimalisasi penerimaan negara di bidang kepabeanan dan cukai sesuai dengan ketentuan peraturan perundang-undangan.

\section{Visi dan Misi}

a. Visi
1) Menjadi Institusi Kepabeanan dan Cukai Terkemuka di Dunia.

2) DJBC mencerminkan citacita tertinggi DJBC dengan lebih baik melalui penetapan target yang menantang dan secara terus-menerus terpelihara di masa depan.

b. Misi

1) Kami memfasilitasi perdagangan dan industri

2) Kami menjaga perbatasan dan melindungi masyarakat Indonesia dari penyelundupan dan perdagangan illegal; dan

3) Kami optimalkan penerimaan negara di sektor kepabeanan dan cukai.

Misi ini merupakan langkah spesifik yang harus dikerjakan DJBC demi tercapainya visi DJBC.peran serta secara keseluruhan terkait dengan besaran perdagangan, keamanan dan penerimaan merupakan satu kesatuan yang tidak terpisahkan.

\section{Fungsi Direktorat Jenderal} Bea dan Cukai

a. Meningkatkan pertumbuhan industri dalam negeri melalui 
JURNAL

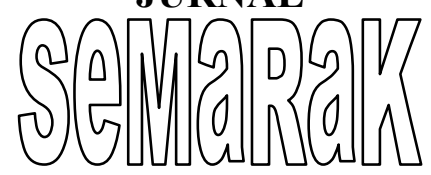

Semarak,Vol. 1, No.3,Oktober 2018, Hal (1-20)

@Prodi Manajemen Fakultas Ekonomi Universitas Pamulang

pemberian fasilitas di bidang kepabeanan dan cukai yang tepat sasaran

b. Mewujudkan iklim usaha dan investasi yang kondusif dengan memperlancar logistik impor dan ekspor melalui penyederhanaan prosedur kepabeanan dan cukai serta penerapan sistem manajemen risiko yang handal;

c. Melindungi masyarakat, industri dalam negeri, dan kepentingan nasional melalui pengawasan dan/atau pencegahan masuknya barang impor dan keluarnya barang ekspor yang berdampak negatif dan berbahaya yang dilarang dan/atau dibatasi oleh regulasi;

d. Melakukan pengawasan kegiatan impor, ekspor dan kegiatan di bidang kepabeanan dan cukai lainnya secara efektif dan efisien melalui penerapan sistem manajemen risiko yang handal, intelijen, dan penyidikan yang kuat, serta penyidikan yang tegas dan audit kepabeanan dan cukai yang tepat;

e. Membatasi, mengawasi, dan/atau mengendalikan produksi, peredaran dan konsumsi barang tertentu yang mempunyai sifat dan karakteristik dapat membahayakan kesehatan, lingkungan, ketertiban, dan keamanan masyarakat melalui instrumen cukai yang memperhatikan aspek keadilan dan keseimbangan; dan

f. Mengoptimalkan penerimaan negara dalam bentuk bea masuk, bea keluar, dan cukai guna menunjang pembangunan nasional

\section{B. Hasil Penelitian}

Data yang digunakan dalam penelitian ini adalah data primer. Data primer dalam penelitian ini diperoleh dengan cara menyebar kuesioner kepada pegawai Sub Direktorat Penindakan Bea dan Cukai.Sampel dalam penelitian ini berjumlah 100 responden, yang diberikan kuesioner tentang komitmen organisasi, kompensasi, kepuasan kerja dan kinerja karyawan.Dari 100 kuesioner yang didistribusikan, 100 kuesioner kembali kepada peneliti dan dapat diolah.Adapun hasil penelitian yang diperoleh dari lapangan disajikan sebagai berikut.

\section{Analisis Deskriptif}

Analisis deskriptif dalam penelitian ini meliputi analisis karakteristik responden, analisis statistik deskriptif dan kategori jawaban responden. Adapun pembahasan mengenai masingmasing analisis deskriptif disajikan sebagai berikut :

\section{a. Karakteristik Responden} Karakteristik responden yang diamati dalam penelitian ini meliputi usia/umur, jenis kelamin, pendidikan, masa kerja dan gaji. Hasil analisis ditunjukkan pada tabel - tabel berikut ini

1) Usia/Umur Deskripsi karakteristik responden berdasarkan usia disajikan pada tabel berikut ini : 
JURNAL

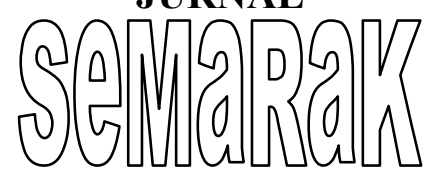

Semarak,Vol. 1, No.3,Oktober 2018, Hal (1-20)

@Prodi Manajemen Fakultas Ekonomi Universitas Pamulang

Kompensasi pada

Sub Direktorat Penindakan

Bea dan Cukai mendapat respon sangat baik, peneliti menyimpulkan berdasarkan hasil jawaban responden yang berjumlah 100 orang dengan 15 pernyataan, yang menjawab "Sangat Tidak Setuju" adalah sebanyak 0 atau $0 \%$, jawaban "Tidak Setuju" sebanyak 4atau 1\%, jawaban "Ragu" sebanyak 154 atau $10 \%$, jawaban "Setuju" sebanyak 681 atau $45 \%$ dan jawaban "Sangat Setuju" sebanyak 661 atau $44 \%$.

\section{Uji Asumsi Klasik}

Uji asumsi klasik adalah persyaratan ststistik yang harus dipenuhi pada analisis regresi linier berganda.Uji asumsi klasik yang sering digunakan adalah uji normaitas, uji multikolinieritas, uji heteroskedastisitas dan uji autokorelasi. Uji asumsi klasik menggunakan Program Statistical Package For The Social Sciences (SPSS) For Windows Ver. 24. Hasil uji asumsi klasik adalah sebagai berikut:

\section{Uji Normalitas}

Uji normalitas digunakan untuk menguji apakah dalam model regresi, terdapat distribusi

\section{One-Sample Kolmogorov-Smirnov Test}

Unstandardi zed Residual

\begin{tabular}{llr}
\hline $\mathrm{N}$ & & 100 \\
\hline $\begin{array}{l}\text { Normal } \\
\text { Parameters }\end{array}$ & Mean &, 0000000 \\
\cline { 2 - 3 } & $\begin{array}{l}\text { Std. } \\
\text { Deviation }\end{array}$ & 2,01951576 \\
\hline $\begin{array}{l}\text { Most Extreme } \\
\text { Differences }\end{array}$ & Absolute &, 057 \\
\cline { 2 - 3 } & Positive &, 053 \\
\cline { 2 - 3 } & Negative &,- 057 \\
\hline Test Statistic & &, 057 \\
\hline Asymp. Sig. (2-tailed) &, $200^{\mathrm{c}, \mathrm{d}}$ \\
\hline
\end{tabular}

a. Test distribution is Normal.

b. Calculated from data.

c. Lilliefors Significance Correction.

$\mathrm{d}$. This is a lower bound of the true significance. normal antara variabel terikat dan variabel bebas.Apabila distribusi data normal atau mendekati normal, berarti model regresi adalah baik. Pengujian untukmenentukan data terdistribusi normal atau tidak, digunakan cara uji statistik non parametrik. Uji statistik nonparametrik yang digunakan adalah uji One-Sample Kolmogorov-Smirnov (1-Sample 
JURNAL

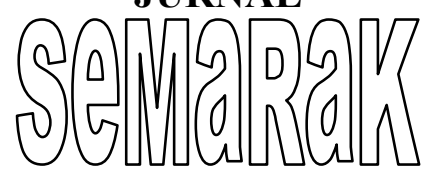

Semarak,Vol. 1, No.3,Oktober 2018, Hal (1-20)

@Prodi Manajemen Fakultas Ekonomi Universitas Pamulang

K-S). Apabila hasilnya menunjukan nilai probabilitas signifikan di atas 0,05, maka variabel terdistribusi normal. Hasilnya sebagai berikut :

Tabel 4. 10

\section{Uji Normalitas}

Sumber : Output SPSS, diolah penulis, 2017

Hasil uji KolmogorovSmirnovpada tabel 4.10 diatas menunjukan Asymp Sig (2-tailed) untuk variabel komitmen organisasi, kompensasi, kepuasan kerja dan kinerja karyawan adalah 0,200 lebih besar dari 0,05 $(0,200>0,05)$, maka dapat disimpulkan bahwa data yang digunakan berdistribusi normal. Untuk lebih jelasnya berikut penulis lampirkan untuk grafik histrogram dan grafik normal Pplot berdistribusi normal, yaitu

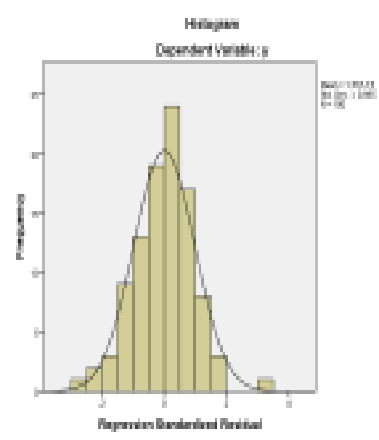

\section{Gambar 4.2 Grafik Histogram}

\section{Gambar 4. 3 Grafik P-Plot}

Sumber : Output SPSS, diolah penulis, 2017
Berdasarkan gambar grafik 4.2 dan 4.3 di atas, dapat dilihat bahwa grafik histogram tidak condong ke kiri dan ke kanan (balance) sehingga dapat disimpulkan data berdistribusi normal. Sedangkan kurva penyebaran P-Plot titik-titik menyebar disekitar garis diagonal dan penyebaranya mengikuti garis diagonal maka dapat disimpulkan bahwa model regresi berdistribusi normal.Dengan demikian uji normalitas menunjukkan terpenuhi asumsi normalitas.

\section{Uji Autokorelasi}

Uji autokorelasi

dilakukan untuk menguji apakah dalam model regresi ada korelasi antara kesalahan pengganggu pada periode $\mathrm{t}$ dengan kesalahan pada periode $\quad \mathrm{t}-1$ (sebelumnya).Jika terjadi korelasi, maka dinamakan ada problem autokorelasi.Model regresi yang baik adalah regresi yang bebas dari autokorelasi.

Berdasarkan tabel 4.11 di atas menunjukan bahwa nilai Durbin-Watson adalah sebesar 2,006. Karena nilai DurbinWatsonterletak antara DU < DW $<4-$ DU $(\mathrm{du}=1,7128)$. 
JURNAL

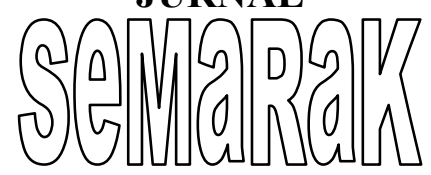

Semarak,Vol. 1, No.3,Oktober 2018, Hal (1-20)

@Prodi Manajemen Fakultas Ekonomi Universitas Pamulang

Maka Ho diterima, artinya tidak terjadi autokorelasi. Tabel durbin-watson adalah sebuah test yang digunakan untuk mendeteksi terjadinya autokorelasi pada nilai residual (Prediction errors) dari sebuah analisis regresi. Yang dimaksud dengan autokorelasi adalah hubungan antara nilai - nilai yang dipisahkan satu sama lain dengan jeda waktu tertentu. Untuk mengetahui tidak

Berdasarkan uji Run Test pada tabel 4.12 di atas menunjukkan bahwa nilai Asymp. Sig. (2-tailed) $>0.05$ diperoleh nilai signifikansi $0,688>0,05$. Karena nilai signifikansi lebih besar dari 0,05 maka dapat disimpulkan bahwa data yang digunakan dalam penelitian ini tidak terjadi masalah autokorelasi.

Berdasarkan tabel $4.13 \mathrm{di}$ atas menunjukan bahwa variabel independen yang digunakan dalam penelitian ini tidak terjadi multikoliniearitas karena nilai VIF $<10$ dan nilai Tolerance $>$ 0,1 . Hal ini dapat dilihat dari besarnya nilai tolerance untuk variabel komitmen organisasi sebesar 1,220, kompensasi 1,081 dan kinerja karyawan 1,293, ketiga variabel tersebut nilai tolerance di atas 0,1 . Sedangkan untuk nilai VIF (Variance Inflation Factor) adalah dibawah 10, sehingga bisa disimpulkan bahwa antar variabel independen tidak terjadi persoalan multikolonieritas

\section{Pembahasan Hasil Penelitian}

Berdasarkan hasil penelitian yang telah diuraikan sebelumnya menunjukkan bahwa terdapat pengaruh positif dan signifikan baik secara parsial maupun simultan komitmen organisasi, kompensasi terhadap kepuasan kerja serta berdampak terhadap kinerja karyawan.

1. Pengaruh Komitmen Organisasi terhadap Kepuasan Kerja pada Sub Direktorat Penindakan Bea dan Cukai

Dari hasil penelitian diketahui adanya pengaruh positif komitmen organisasi terhadap kepuasan kerja. Hal ini dibuktikan dengan pengujian hipotesis pengaruh $\mathrm{x} 1 \quad$ (komitmen organisasi) terhadap y (kepuasan kerja) menunjukan diperoleh nilai nilai $t_{\text {hitung }}$ sebesar 5,025 dengan nilai signifikasi 0,000 dan $t_{\text {tabel }}$ 1,98 . Karena $t_{\text {hitung }}>t_{\text {tabel }}(5,025>$ 1,98) dan signifikansi $<0,05$ 
JURNAL

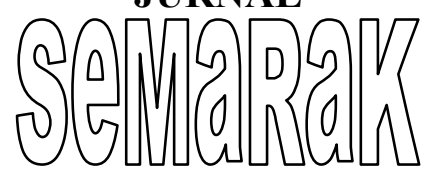

P-ISSN 2615-6849 E-ISSN 2622-3686

Semarak,Vol. 1, No.3,Oktober 2018, Hal (1-20)

@ Prodi Manajemen Fakultas Ekonomi Universitas Pamulang
$(0,000<0,05)$ maka dapat disimpulkan bahwa komitmen organisasi secara parsial berpengaruh positif dan signifikan terhadap kepuasan kerja pada Sub Direktorat Penindakan Bea dan Cukai.

Setiap perusahaan bertujuan untuk mencapai tujuannya dengan menggunakan segenap sumber daya manusia yang dimiliki oleh perusahan itu sendiri. Tujuan setiap sumber daya manusia dalam perusahaan harus dijaga agar selaras dengan tujuan perusahaan untuk lebih meningkatkan kinerja dan mengembangkan perusahaan tersebut. Sumber daya manusia dalam perusahaan harus memiliki kemampuan dan pengetahuan untuk meningkatkan kinerja dalam perusahaan.

Perusahaan memerlukan sumber daya manusia yang mempunyai komitmen yang kuat dalam bekerja karena berkembangnya perusahaan sangat ditentukan oleh kualitas manusia yang memiiki komitmen. Karyawan yang berkomitmen tinggi akan memiliki kinerja yang tingi dan loyalitas terhadap perusahaan. Sebaliknya, karyawan yang cenderung memiliki komitmen yang rendah, kinerjanya pun rendah loyalitas terhadap perusahaan berkurang.

2. Pengaruh Kompensasi terhadap Kepuasan Kerja pada Sub Direktorat Penindakan Bea dan Cukai
Dari hasil penelitian diketahui adanya pengaruh positif kompensasi terhadap kepuasan kerja. Hal ini dibuktikan dengan pengujian hipotesis $\mathrm{x} 2$ (kompensasi) terhadap y (kepuasan kerja) diperoleh nilai $t_{\text {hitung }}$ sebesar 2,720 dengan nilai signifikasi 0,009 dan $t_{\text {tabel }} 1,98$. Karena $t_{\text {hitung }}>t_{\text {tabel }}(2,270>1,98)$ dan signifikansi $<0,05(0,009<$ $0,05)$ maka dapat disimpulkan bahwa kompensasi secara parsial berpengaruh positif dan signifikan terhadap kinerja karyawan pada Sub Direktorat Penindakan Bea dan Cukai.

Kepuasan kerja menyebabkan adanya peningkatan atau penurunan kinerja karyawan sehingga pekerja yang puas akan lebih produktif dibandingkan dengan pekerja yang tidak puas. Apabila terdapat karyawan atau pekerja yang merasakan ketidakpuasan atas pekerjaanya akan menyebabakan kinerjanya menurun. Hal ini mengambarkan adanya hubungan timbal balik antara kepuasan kerja dengan kinerja karyawan.

Untuk meningkatkan kepuasan kerja dalam hal ini yang menjadi prioritas adalah penghasilan dan promosi yang pada akhirnya dapat meningkatkan kinerja perlu dilakukan beberapa langkah konkret antara lain :

Pertama, kesejahteraan dan adanya gaji/imbalan yang dirasakan adil perlu mendapatkan 
JURNAL

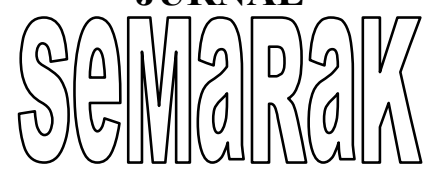

P-ISSN 2615-6849 E-ISSN 2622-3686

Semarak,Vol. 1, No.3,Oktober 2018, Hal (1-20)

@Prodi Manajemen Fakultas Ekonomi Universitas Pamulang perhatian, karena uang atau imbalan akan memberikan dampak terhadap kinerja jika imbalan yang diberikan disesuaikan dengan tingginya prestasi kerja.

$$
\text { Kedua, mengenai }
$$
promosi kerja yang sebaiknya ada dan dilaksanakan oleh perusahaan kepada karyawan yang berprestasi.Hal ini dipandang sebagai penghargaan dari perusahaan atas keberhasilan karyawan yang menunjukan prestasi kerja yang tinggi.

3. Pengaruh Komitmen Organisasi dan Kompensasi terhadap Kepuasan Kerja pada Sub Direktorat Penindakan Bea dan Cukai

Dari hasil penelitian diketahui adanya pengaruh positif komitmen organisasi dan kompensasi terhadap kepuasan kerja.Hal ini dibuktikan dengan pengujian hipotesis $\mathrm{x} 1$ (komitmen organisasi) dan $\mathrm{x} 2$ (kompensasi) terhadap y (kepuasan kerja) diperoleh nilai $\mathrm{f}_{\text {hitung }}$ sebesar 13,427 dan nilai signifikansi sebesar 0,000 . Nilai $\mathrm{f}_{\text {tabel }}$ pada tingkat kepercayaan $5 \%$ dengan $\mathrm{df} 1=2$ dan $\mathrm{df} 2=$ 98, maka didapatkan $f_{\text {tabel }}=3,09$. Karena $f_{\text {hitung }}>f_{\text {tabel }}(13,427>$ $3,09)$ dan nilai signifikan $<0,05$ $(0,000<0,05)$ maka dapat disimpulkan bahwa variabel komitmen organisasi dan kompensasi berpengaruh positif dan siginifikan terhadap kepuasan kerja karyawan pada
Sub Direktorat Penindakan Bea dan Cukai.

Dalam hal ini perusahaan

hendaknya senantiasa

memperhatikan dan meningkatkan komitmen karyawannya dalam bekerja. Bila karyawan komitmen terhadap organisasi, maka akan membuat kepuasan kerja yang berdampak pada komitmen organisasi yang akan membuat kinerja karyawan diperusahaan menjadi lebih efektif dan efisien karena semua hal itu sudah tertanam dalam diri karyawan. Sehingga karyawan akan memilki tujuan untuk dapat bertanggung jawab membantu perusahaan untuk mencapai tujuannya.

Perlakuan perusahaan dan kebijakan perusahaan akan memberikan kepuasan kerja terhadap karyawannya, sehingga kinerja karyawan pun kinerjanya akan meningkat. Hal ini akan 
JURNAL

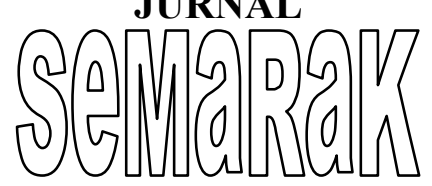

Semarak,Vol. 1, No.3,Oktober 2018, Hal (1-20)

@Prodi Manajemen Fakultas Ekonomi Universitas Pamulang

berdampak pada semakin baiknya

perkembangan

perusahaan

sehingga tercapailah tujuannya.

$$
\text { Kompensasi yang }
$$

diberikan sesuai dengan

kinerjanya karyawan pun akan

memberikan dampak yang baik

bagi perusahaan. Karyawan akan

merasa betah dan semangat

bekerja sehingga dapat

meningkatnya kinerja karena

mereka mendapatkan kompensasi

yang sesuai dengan kinerja dan

keterampilanya. Perusahaan akan

dipandang bagus oleh para

karyawannya maupun oleh

instansi terkait dengan

keperburuhan.

4. Pengaruh Komitmen Organisasi terhadap Kinerja Karyawan pada Sub Direktorat Penindakan Bea dan Cukai

Dari hasil penelitian

diketahui adanya pengaruh

positif komitmen organisasi

terhadap kinerja karyawan. Hal

ini dibuktikan Pengujian

hipotesis $\mathrm{x} 1 \quad$ (komitmen organisasi) terhadap $\mathrm{z}$ (kinerja karyawan) diperoleh nilai nilai $t_{\text {hitung }}$ sebesar 4,638 dengan nilai signifikasi 0,000 dan $t_{\text {tabel }} 1,98$. Karena $t_{\text {hitung }}>t_{\text {tabel }}(4,638>1,98)$ dan signifikansi $<0,05(0,000<$ 0,05) maka dapat disimpulkan bahwa komitmen organisasi secara parsial berpengaruh positif dan signifikan terhadap kepuasan kerja pada Sub Direktorat Penindakan Bea dan Cukai.

Salah satu faktor yang berpengaruh terhadap kinerja adalah komitmen. Karyawan yang berkomitmen rendah akan berdampak pada turn-over yang tinggi. Namun apabila karyawan memiliki komitmen yang tinggi pada perusahaan maka karyawan akan cenderung tetap bekerja pada perusahaan dan juga akan berpengaruh positif terhadap kinerja karyawan juga perusahaan. 
JURNAL

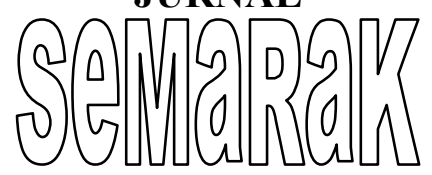

Semarak,Vol. 1, No.3,Oktober 2018, Hal (1-20)

@Prodi Manajemen Fakultas Ekonomi Universitas Pamulang

5. Pengaruh Kompensasi terhadap Kinerja Karyawan pada Sub Direktorat Penindakan Bea dan Cukai

Dari hasil penelitian diketahui adanya pengaruh positif kompensasi terhadap kinerja karyawan. Hal ini dibuktikan dengan pengujian hipotesis $\mathrm{x} 2$ (kompensasi) terhadap $\mathrm{z}$ (kinerja karyawan) diperoleh nilai $t_{\text {hitung }}$ sebesar 2,811 dengan nilai signifikasi 0,006 dan $t_{\text {tabel }} 1,98$. Karena $t_{\text {hitung }}>t_{\text {tabel }}(2,811>1,98)$ dan signifikansi $<0,05(0,006<$ $0,05)$ maka dapat disimpulkan bahwa kompensasi secara parsial berpengaruh positif dan signifikan terhadap kinerja karyawan pada Sub Direktorat Penindakan Bea dan Cukai.

Kompensasi karyawan merupakan elemen hubungan kerja yang sering menimbulkan masalah dalam hubungan perusahaan.Manajemen

perusahaan memperhitungkan upah atau imbalan karena merupakan bagian utama dari biaya produksi dan operasi, melukiskan kinerja karyawan yang harus dibayar dan mempengaruhi kemempuanya untuk merekrut tenaga kerja dengan kualitas tertentu.

Kompensasi yang diberikan kepada karyawan menentukan kemamampuan perusahaan untuk mendapatkan keuntungan.Oleh karena itu, jika memungkinkan manajemen berupaya menefesiensikan upah karyawan dengan pembayaran minimal tetapi karyawan harus berkerja secara optimal.

6. Pengaruh Kepuasan Kerja terhadap Kinerja Karyawan pada Sub Direktorat Penindakan Bea dan Cukai

Dari hasil penelitian diketahui adanya pengaruh positif kepuasan kerja terhadap kinerja karyawan. Hal ini dibuktikan dengan pengujian hipotesis pengaruh y (kepuasan kerja) terhadap z (kinerja karyawan) diperoleh nilai nilai $t_{\text {hitung }}$ sebesar 18,941 dengan nilai signifikasi 0,000 dan $t_{\text {tabel }} 1,98$. Karena $t_{\text {hitung }}$ $>t_{\text {tabel }}(18,941>1,98)$ dan signifikansi $<0,05(0,000<0,05)$ maka dapat disimpulkan bahwa kepuasan kerja secara parsial berpengaruh positif dan signifikan terhadap kinerja karyawan pada Sub Direktorat Penindakan Bea dan Cukai.

Penilaian keinerja karyawan meruapakan salah satu tugas penting yang harus dilakukan oleh perusahaan.Kegiatan penilaian ini penting, karena dapat digunakan untuk memperbaiki keputusan keputusan perusahaan untuk memeberikan umpan balik kepada para karyawan tentang kinerja mereka.

Terdapat berbagai faktor yang mempengaruhinya terutama kepuasan kerja. Semakin puas karyawan atas kinerjanya maka seorang karyawan akan terpacu untuk memiliki kinerja yang semakin tinggi atau baik. 


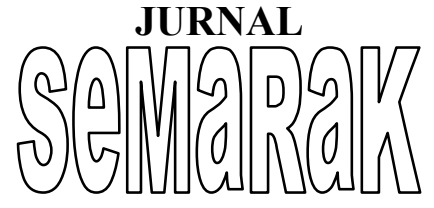

\section{P-ISSN 2615-6849 E-ISSN 2622-3686}

Semarak,Vol. 1, No.3,Oktober 2018, Hal (1-20)

(a)Prodi Manajemen Fakultas Ekonomi Universitas Pamulang

\section{A. Kesimpulan}

Berdasarkan hasil analisis dan pembahasan yang telah dijelaskan sebelumnya mengenai Pengaruh Komitmen Organisasi dan Kompensasi terhadap Kepuasan Kerja serta Dampaknya terhadap Kinerja Karyawan pada Sub Direktorat Penindakan Bea dan Cukai, maka penulis mengambil kesimpulan sebagai berikut :

1. Komitmen organisasi memiliki pengaruh yang positif dan signifikan terhadap kepuasan kerja dengan uji $\mathrm{t}$ (parsial) diperoleh nilai $t_{\text {hitung }}$ sebesar 5,025 dengan nilai signifikasi 0,000 dan $t_{\text {tabel }} 1,98$. Karena $t_{\text {hitung }}$ $>t_{\text {tabel }}(5,025>1,98)$ dan signifikansi $<0,05(0,000<0,05)$ maka dapat disimpulkan bahwa komitmen organisasi secara parsial berpengaruh positif dan signifikan terhadap kepuasan kerja pada Sub Direktorat Penindakan Bea dan Cukai.

2. Kompensasi memiliki pengaruh yang positif dan signifikan terhadap kepuasan kerja dengan uji t (parsial) diperoleh nilai nilai $\mathrm{t}_{\text {hitung }}$ sebesar 2,720 dengan nilai signifikasi 0,009 dan $t_{\text {tabel }} 1,98$. Karena $t_{\text {hitung }}>t_{\text {tabel }}(2,270>1,98)$ dan signifikansi $<0,05(0,009<$ $0,05)$ maka dapat disimpulkan bahwa kompensasi secara parsial berpengaruh positif dan signifikan terhadap kinerja karyawan pada Sub Direktorat Penindakan Bea dan Cukai.

3. Komitmen organisasi dan kompensasi memiliki pengaruh yang positif dan signifikan terhadap kepuasan kerja berdasarkan uji $f$ (simultan) diperoleh nilai $f_{\text {hitung }}$ sebesar 13,427 dan nilai signifikansi sebesar 0,000 . Nilai $\mathrm{f}_{\text {tabel }}$ pada tingkat kepercayaan 5\% dengan df1 $=2$ dan df2 $=98$, maka didapatkan $\mathrm{f}_{\text {tabel }}=3,09$. Karena $f_{\text {hitung }}>\mathrm{f}_{\text {tabel }}(13,427>3,09)$ dan nilai signifikan $<0,05 \quad(0,000<$ $0,05)$ maka dapat disimpulkan bahwa variabel komitmen organisasi dan kompensasi berpengaruh positif dan siginifikan terhadap kepuasan kerja karyawan pada Sub Direktorat Penindakan Bea dan Cukai.

4. Komitmen organisasi berpengaruh positif dan signifikan terhadap kinerja karyawan dengan uji $\mathrm{t}$ (parsial) diperolehnilai $\mathrm{t}_{\text {hitung }}$ sebesar 4,638 dengan nilai signifikasi 0,000 dan $t_{\text {tabel }} 1,98$. Karena $\mathrm{t}_{\text {hitung }}>\mathrm{t}_{\text {tabel }}(4,638>1,98)$ dan signifikansi $<0,05(0,000<$ $0,05)$ maka dapat disimpulkan bahwa komitmen organisasi secara parsial berpengaruh positif dan signifikan terhadap kepuasan kerja pada Sub Direktorat Penindakan Bea dan Cukai.

5. Kompensasi berpengaruh positif dan signifikan terhadap kinerja karyawan dengan uji $\mathrm{t}$ (parsial) diperoleh nilai $t_{\text {hitung }}$ sebesar 2,811 dengan nilai signifikasi 0,006 dan $t_{\text {tabel }}$ 1,98. Karena $t_{\text {hitung }}>t_{\text {tabel }}$ $(2,811>1,98)$ dan signifikansi $<$ $0,05(0,006<0,05)$ maka dapat disimpulkan bahwa kompensasi secara parsial berpengaruh positif dan signifikan terhadap kinerja karyawan pada Sub Direktorat Penindakan Bea dan Cukai.

6. Kepuasan kerja berpengaruh positif dan signifikan terhadap kinerja karyawan dengan uji $\mathrm{t}$ (parsial) diperoleh nilai $t_{\text {hitung }}$ sebesar 18,941 dengan nilai signifikasi 0,000 dan $t_{\text {tabel }} 1,98$. Karena $\mathrm{t}_{\text {hitung }}>\mathrm{t}_{\text {tabel }}(18,941>$ $1,98)$ dan signifikansi $<0,05$ $(0,000<0,05)$ maka dapat disimpulkan bahwa kepuasan kerja secara parsial berpengaruh 


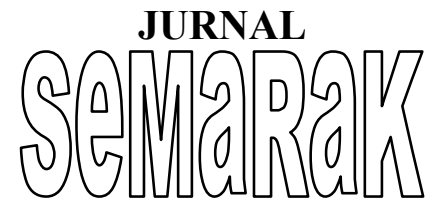

P-ISSN 2615-6849 E-ISSN 2622-3686

Semarak,Vol. 1, No.3,Oktober 2018, Hal (1-20)

@Prodi Manajemen Fakultas Ekonomi Universitas Pamulang positif dan signifikan terhadap kinerja karyawan pada Sub Direktorat Penindakan Bea dan Cukai.

\section{DAFTAR PUSTAKA}

A.A Anwar Prabu Mangkunegara. 2005. Manajemen sumber daya manusia perusahaan. Bandung: PT. Remaja Rosdakarya.

Achmad Badjuri (2009). Pengaruh Komitmen Prganisasional dan Profesiaonal Terhadap Kepuasan Kerja Auditor Dengan Motivasi sebagai Variabel intervening. Kajian Akuntansi, Agustus 2009, Hal: 117-132 Vol. 1 No. 2117

Ardana, Komang; Wayan Mujiati, Wayan Mudiartha Utama. 2011. Manajemen Sumber Daya Manusia. Denpasar : Graha Ilmu.Yogyakarta.

Arikunto, Suharsimi. 2002. Prosedur Suatu Penelitian: Pendekatan Praktek. Jakarta: PT. Rineka Cipta.As'ad, M.. Psikologi Industri, Seri Umum. Sumber Daya Manusia. Edisi 4. Liberty, Yogyakarta 2004

Cherrington, David J,. 2007. Organizational Behavior : The Management of Individual and Organizational Performance, Second Edition, Allyn \& Bacon, Boston.

Darlis, Edfan, 2002, Analisis Pengaruh Komitmen Organisasional dan Ketidakpastian Lingkungan terhadap Hubungan antara Partisipasi Anggaran dengan Senjangan Anggaran, Jurnal Riset dan Akuntansi Indonesia, Vol.5, No.1.
Dessler, Gary. (2007). Manajemen Sumber Daya Manusia. Jakarta: PT. Indeks.

Emzir.2008. Metodologi Penelitian Kuantitatif dan Kualitatif.Jakarta: Raja Grafindo Persada.

Frederrick Herzberg, 2003. Dasar-Dasar Manajemen.Diterjemahkan oleh Malayu S.P Hasibuan. Edisi Kedua. Jakarta : Bumi Aksara

Frildawati, Devi. 2009. Analisis Faktor-Faktor Yang Mempengaruhi Audit Delay.Skripsi.Fakultas Ekonomi dan Ilmu Sosial Universitas Islam Negeri Syarif Hidayatullah. Jakarta

Garry Dessler, 2008.Human Resource Management.Edisi Sebelas, New Jersey : Pearson Education, Inc.

Gathungu, James, Hannah Wachira W. 2013 . Job Satisfaction Factors that Influence the Performance of Secondary School Principals in their Administrative Functions in Mombasa District, Kenya. International Journal of Education and Research. Vol. 1 No 2, pp. $257-270$

Gerhart, B., \& Milkovich, G. T. 2002. Employee compensation: Research and practice. In M. D. Dunnette \& L. M. Hough (Eds.), Handbook of industrial and organizational psychology, (Vol. 3, 2nd ed., pp. 481570). Palo Alto, CA: Consulting Psychologists Press.

Gibson, James L, John M. Ivancevich dan James H. Donnelly Jr, 2000. Organizations: Behaviour, Structure and Process, McGraw-Hill

Companies Inc, Boston. 


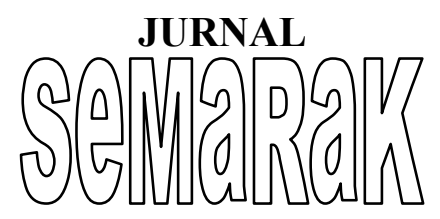

P-ISSN 2615-6849 E-ISSN 2622-3686

Semarak,Vol. 1, No.3,Oktober 2018, Hal (1-20)

@Prodi Manajemen Fakultas Ekonomi Universitas Pamulang
Harnoto.(2002). Manajemen Sumber Daya Manusia. Jakarta: PT. Prehallindo.

Hasibuan, Malayu S.P. 2007. Organisasi dan Motivasi. Cetakan Keempat. Bumi Aksara. Jakarta.

Heidjrachman Ranupandojo dan Suad Husnan. 2002. Manajemen Personalia. Yogyakarta: BPFE

Hersusdadikawati, Endang. (2004). Pengaruh Kepuasan Atas Gaji Terhadap Keinginan Untuk Berpindah Kerja, Dengan Komitmen Organisasional Sebagai Variabel Intervening : Studi Empiris Pada Dosen Akuntansi Perguruan Tinggi Swasta Jawa Tengah. Semarang: Program Pasca Sarjana Universitas Diponegoro.

Istijanto.(2010). Riset Sumber Daya Manusia. Jakarta: PT. Gramedia Pustaka.

Jenkins, G. D.; Gupta, N.; Mitra, A.; dan Shaw, J. (2001). Are Financial Incentives Related to Performance? A Meta-Analytic Review of Empirical Research. Jurnal of Applied Psychology, Vol. 83, 777-787.

Kuncoro, Mudrajad (2001). Metode Penelitian Kuantitatif. Yogyakarta: UPP AMP YKPM.

Lawler. E.E dan Jenkins, 2002, Strategic Reward system, Hand Book of Industrial and Organization Psychology, Vol.3, Consulting Pschologi Prres.

Luthans, Fred. 2006. Perilaku Organisasi, edisi 10. Penerbit Andi, Yogyakarta.

Martoyo, Susilo. 2007. Manajemen Sumber Daya Manusia. BPFE.Yogyakarta.
Mathis Robert L. dan Jackson, John H. 2006, Human Resource Management, alih Bahasa. Salemba Empat. Jakarta.

Mathis, Robert L \& Jackson, John $\mathrm{H}$. 2009.Manajemen Sumber Daya Manusia. Jakarta: Salemba Empat.

Mayer, R. E., 2009. Multimedia Learning: Prinsip-prinsip dan Aplikasi, Yogyakarta: Pustaka Pelajar.

Mobley, William H. (2011). Pergantian Karyawan : Sebab, Akibat dan Pengendaliannya. Jakarta: PPm Manajemen.

Mondy, Wayne R. (2008). Manajemen Sumber Daya Manusia. Jakarta: Erlangga.

Munandar, Ashar S. (2011). Psikologi Industri dan Organisasi. Jakarta: UI Press.

Ncube and Samuel, 2014, "RevisitingEmployee Motivation and JobSatisfaction within the Context of anEmerging Economy: TheoreticalRepresentation and Developing theModel" Mediterranean Journal ofSocial Sciences MCSER Publishing,Rome-Italy, Vol. 5 No. 9

Noe, Raymond A. et al. (2010). Manajemen Sumber Daya Manusia : Mencapai Keunggulan Bersaing 2011. Jakarta: Salemba Empat.

Nugraeni. (2004). Pengaruh Kepuasan Kerja dan Komitmen Organisasi Terhadap Turnover Intention Akuntan Pendidik (Dosen Akuntansi) di Perguruan Tinggi Swasta Daerah Istimewa Yogyakarta. Vol. 4. November. 


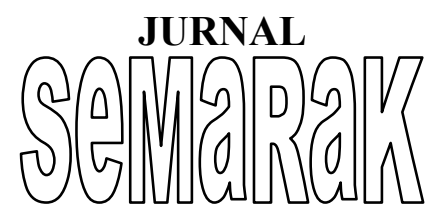

Semarak,Vol. 1, No.3,Oktober 2018, Hal (1-20)

@Prodi Manajemen Fakultas Ekonomi Universitas Pamulang

Panggabean, Mutiara S. (2004). Manajemen

Sumber Daya Manusia. Bogor:

Ghalia Indonesia.

Purwanto.2010. Evaluasi Hasil belajar. Yogyakarta: Pustaka Pelajar.

Porter, M., Sachs, J., \& McArthur, J. (2002). Executive summary: Competitiveness and stages of economic development. In M. Porter, J. Sachs, P. K. Cornelius, J. W. McArthur, \& K. Schwab (Eds.), The global competitiveness report 2001-2002 (pp. 16-25). New York: Oxford University Press.

Rivai Veithzal, 2008, Manajemen Sumber Daya Manusia Untuk Perusahaan : dari Teori dan Praktik, PT. RajaGrafindo Persada, Jakarta

Roberts, James A. \& Chonko, Lawrence B. (2000). Pay Satisfaction and Sales Force Turnover : The Impact of Different Facets of Pay on Pay Satisfaction and Its Implication For Sales Force Management. Journal of Managerial Issues. Vol. 8Robbbins dan Judge. 2007. Perilaku Organisasi, Buku 1 dan 2. Jakarta : Salemba Empat

Robbins, Stephen P. 2003. Perilaku Organisasi, Edisi 9. Prentice Hall, Jakarta.

Robbins, Stephen P.-Timothy A. Judge. 2008. Perilaku Organisasi. Edisi 2- Buku 1. Jakarta. Salemba Empat.

Robbins, Stephen P. (2010). Perilaku Organisasi. Jakarta: Salemba Empat.

Singh, Parbudyal. (2010). Pay Satisfaction, Job Satisfaction and Turnover
Intention.Journal of Industrial Relations.Vol. 65 No. 3.

Sopiah. 2008. Perilaku Organisasional. Edisi Pertama. Andi.Yogyakarta.

Sugiyono.(2010). Metode Penelitian Bisnis. Bandung: Alphabeta.

Tanajaya, M. dan Noegroho, S. (2000). Perbedaan Faktor-Faktor Keikatan Kerja Karyawan terhadap Organisasi Ditinjau dari Jenis Kelamin.Jurnal Psikologi Indonesia. No 1 (8-16).

Tian, Wei (Amy). (2009). Job Satisfaction and Turnover In The Chinese Retail. Journal of Chinese Management Studies.Vol. 3 No. 4.

Toly, Agus A. (2001).Analisis Faktor-Faktor Yang Mempengaruhi Turnover Intention Pada Staf Kantor Akuntan Publik.Jurnal Akuntansi dan Keuangan.Vol. 3, No. 2.

Umar, Husein. 2005. Riset Pemasaran dan Perilaku Konsumen, Cetakan keempat. Jakarta: PT Gramedia Pustaka Utama.

Wells, Janelle E. \& Peachey, John Welty. (2011). Turnover Intention: Do Leadership Behaviors and Satisfaction With The Leader Matter?.Journal of Team Performance Management.Vol. 17 No. $1 / 2$. 